\title{
Phytochemical, Free Radical Scavenging Activity and Thin Layer Chromatography Analysis of Methanolic Extracts of Six Wild Mushroom Species Collected From the Shai Hills Reserve of Ghana
}

\author{
Ebenezer Owusu ${ }^{1 *}$, Gladys Schwinger ${ }^{1}$, Matilda Dzomeku' ${ }^{2}$, Mary Obodai ${ }^{2}$ and Isaac Asante ${ }^{1}$
}

\section{Ebenezer Owusu1*, Gladys Schwinger ${ }^{1}$, Matilda Dzomeku², Mary Obodai $^{2}$ and Isaac Asante ${ }^{1}$ \\ 'Dept. of Plant and Environmental Biology, University of Ghana, Legon- Accra, GHANA. \\ ${ }^{2}$ CSIR-Food Research Institute, $P, O, B o x$, M20, Accra, GHANA. \\ Correspondence}

Ebenezer Owusu

Department of Plant and Environmental Biology, University of Ghana, LegonAccra, GHANA.

Phone no: 233-264-263531

E-mail: eowusu@ug.edu.gh

History

- Submission Date: 16-05-2017;

- Review completed: 21-07-2017;

- Accepted Date: 17-08-2017

DOI : 10.5530/pj.2017.6s.152

Article Available online

http://www.phcogj.com/v9/i6s

Copyright

(C) 2017 Phcog.Net. This is an openaccess article distributed under the terms of the Creative Commons Attribution 4.0 International license.

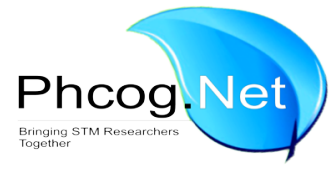

\begin{abstract}
Objective: Six different mushroom species (Termitomyces, Ganoderma, Amauroderma, Mycena, Marasmus and an unknown) were studied to ascertain their phytochemical and antioxidant properties and determine theirTLC analysis of methanolic extracts. Materials and Methods:The DPPH (1,1-diphenyl-2-picrylhydrazyl) model was employed to determine free radical scavenging activity of the methanolic extracts of the mushrooms, aluminum chloride calorimetric method for flavonoid, Thin layer chromatography (TLC) for retention factor and atomic absorption spectrophotometric (AAS) for macro and micronutrients. Results: Phytochemical analyses of the methanolic extract revealed the presence of antioxidants, phenols and flavonoids. The antioxidant values $\left(\mathrm{IC}_{50}(\mu \mathrm{g} / \mathrm{ml})\right)$ ranged from $1.56 \times 10^{-4}$ to $21.07 \times 10^{-4}$. Total phenol content ranged between 2.54 and $17.53 \mathrm{mg} / \mathrm{g}$ GAE with a mean of about $11.27 \mathrm{mg} / \mathrm{g} \mathrm{GAE}$. Total flavonoid content also ranged from 5.46 to $23.75 \mathrm{mg} / \mathrm{g} R U E$ with a mean of $13.41 \mathrm{mg} / \mathrm{g}$ RUE. Micronutrients such as cadmium, iron, lead, manganese and zinc were determined. Also macronutrients determined included, calcium, potassium, magnesium and sodium. Sodium ranged the highest with values ranging $6966.67 \mathrm{mg} / \mathrm{L}$ to $9600.00 \mathrm{mg} / \mathrm{L}$ followed by iron ranging from 1613.67 to $3040.00 \mathrm{mg} / \mathrm{L}$. Percentage crude protein ranged between $11.09 \%$ and $28.24 \%$. Alkaloid was present in only Mycena sp and Ganoderma sp with a band each of $R_{f}$ value of 0.49. A total of 18 different bands were recorded for flavonoid with $R_{f}$ values that ranged between 0.20 and 0.97 , respectively. Conclusion: The antioxidant potential of the methanolic extracts of the mushroom samples in this study recorded higher values. This indicates that mushrooms have high antioxidant properties and rationalizes further investigation in the potential discovery of new natural bioactive principles from these mushrooms.
\end{abstract}

Key words: Antioxidant, Extracts, Flavonoids, Mushrooms, Phytochemical.

\section{INTRODUCTION}

Mushrooms are low in calories and high in proteins, vitamins and minerals and they therefore serve as valuable, healthy foods. ${ }^{1}$ Currently, the consumption of wild edible mushroom is increasing as a result of their good source of protein and micronutrients. ${ }^{2}$ Apart from their healthy food source, mushrooms serve as therapeutic foods and are also useful in the management of such diseases as hypertension, hypercholesterolemia and cancer, diabetes, neurodegenerative disorders and cardiovascular disorders. Mushrooms are also good sources of antioxidants and are therefore possible protective agents for the reduction of oxidative damage in humans without any side effects. ${ }^{3}$ In recent times edible mushrooms have attracted interest as functional foods as well as source of bioactive metabolites for the development of drugs and nutraceuticals. ${ }^{4,5}$ Some have also been found to be a source of phenolic compounds, ${ }^{6}$ flavonoids, terpenoids, sterols, ascorbic acid, ergothioneine and carotenoids. ${ }^{3,4,5,6,7}$

Various methods are available for the screening of pharmacologically active substances in extracts. One such method is the thin layer chromatography (TLC), a simple, quick reliable and inexpensive procedure that can be used for screening of plant extracts. ${ }^{8}$ The TLC is also very useful for preliminary study before other instrumental techniques are applied., ${ }^{9,10}$ The use of TLC for separation and purification of plant constituents depends on their size, shape and charge. ${ }^{11}$ It serves as a quick way for monitoring the identity and purity of drugs; it is also used for detecting adulterations and substitutions, drug combination analysis and phytochemical preparations. $^{12,13}$

Cite this article: Owusu E, Schwinger G, Dzomeku M, Obodai M and Asante I. Phytochemical, Free Radical Scavenging Activity and Thin Layer Chromatography Analysis of Methanolic Extracts of Six Wild Mushroom Species Collected From the Shai Hills Reserve of Ghana. Pharmacog J. 2017;9(6) Suppl:s16-s22. 
The aim of this study was to characterize mushroom species collected from Shai Hills Reserve in Ghana on the basis of their nutrient content, phytochemical constituents and antioxidant potentials.

\section{MATERIALS AND METHODS}

\section{Sample collection}

Mushroom samples were collected from the Shai Hills Reserve in Ghana in 2014. These were collected in brown large envelopes and identified using cultural and morphological characteristics. ${ }^{14,15}$ The samples were later sun-dried and kept in the freezer until ready for use.

\section{Preparation of sample}

Mushroom samples were prepared by following a modified approach. ${ }^{16}$ The mushrooms were lyophilized (Labconco, Missouri) and pulverized into fine powder. Ten grams of the pulverized samples was extracted with $100 \mathrm{ml}$ of methanol at $25^{\circ} \mathrm{C}$ at $20 \mathrm{~g}$ for 24 hours and filtered through Whatman No. 1 filter paper. The residue was extracted with two additional $100 \mathrm{ml}$ portions of methanol as described above and combined ethanolic extracts were concentrated under reduced pressure below $40^{\circ} \mathrm{C}$ to obtain the crude extract. The crude extracts were re-dissolved in methanol at concentration $20 \mathrm{mg} / \mathrm{ml}$ and stored at $4^{\circ} \mathrm{C}$ for further analyses.

\section{Antioxidant Activity (DPPH Free Radical Scavenging Activity) of Methanolic Extract}

The diluted working solutions of the test extracts were prepared in methanol. Accurately $100 \mu \mathrm{l}$ of test samples $(0.6-20.0 \mathrm{mg} / \mathrm{ml})$ in methanol was added with $5 \mu \mathrm{l}$ DPPH solution in 96-well microtitter plates. An amount of $0.002 \%$ DPPH was prepared in methanol. One microliter of this solution was mixed with $1 \mathrm{ml}$ of sample solution and the standard solution to be tested separately. These solution mixtures were kept in the dark for $20 \mathrm{~min}$ and optical density was measured at $517 \mathrm{~nm}$ using a spectrophotometer against methanol. The blank was used as $1 \mathrm{ml}$ of methanol with $1 \mathrm{ml}$ of DPPH solution $(0.002 \%)$. The optical density was recorded and percent of inhibition was calculated using the formula given below.

Percent inhibition of DPPH activity $=(\mathrm{A}-\mathrm{B} / \mathrm{A}) \times 100$ where $\mathrm{A}$ is optical density of the blank and $B$ is optical density of the sample.

\section{Statistics and $\mathrm{IC}_{50}$}

Decolorization was plotted against the sample extract concentration and a linear regression curve was established in order to calculate $\mathrm{IC}_{50}(\mu \mathrm{g} / \mathrm{ml})$, which is the amount of sample required to decrease the absorbance of the DPPH free radical by 50\%. All the analyses were carried out in triplicate and the results expressed as mean \pm SD. Statistical analyses were performed using SAS computer software

\section{Determination of total phenol content}

Total phenolic content in the methanolic extracts was determined by using Folin-Ciocalteau reagent based on modified version. ${ }^{17}$ Each sample $(150 \mu \mathrm{l}, 10 \mathrm{mg} / \mathrm{ml})$ was added with $1200 \mu \mathrm{l}$ distilled water and $450 \mu \mathrm{l}$ aqueous sodium carbonate solution. One hundred microliters of FolinCiocalteu reagent was added to the mixture and agitated. The mixture was allowed to stand for 90 minutes and the absorbance was measured at $760 \mathrm{~nm}$ by using UV/visible spectrophotometer (SpectraMax Plus384, United States). The concentration of total phenolic compounds was calculated based on standard curve of gallic acid $(0.2-1.0 \mathrm{mg} / \mathrm{ml})$ with the linear equation, $y=0.624 x-0.939$, where $R 2=0.995$. The results were expressed as $\mu \mathrm{g}$ of gallic acid equivalent (GAE/ $\mu \mathrm{g})$ per gram of the extracts.

\section{Determination of total flavonoid content}

The modified aluminum chloride colorimetric method ${ }^{18}$ was used to determine flavonoid content. Mushroom extract $(100 \mu \mathrm{l}, 10 \mathrm{mg} / \mathrm{ml})$ was mixed with distilled $500 \mu$ water and sodium nitrite, $\mathrm{NaNO}_{2}(5 \%, 30 \mu \mathrm{l})$. The mixture was allowed to stand for 5 minutes. Aluminium chloride solution, $\mathrm{AlCl}_{3} \cdot \mathrm{H}_{2} \mathrm{O}(10 \%, 60 \mu \mathrm{l})$ was added to the mixture and left for 6 minutes. Sodium hydroxide, $\mathrm{NaOH}(1 \mathrm{M}, 200 \mu \mathrm{l})$ and $110 \mu \mathrm{l}$ distilled water were added to the solution and mixed well. Absorbance of the solution was measured at $510 \mathrm{~nm}$ (SpectraMax Plus384, United States) and the concentration of total flavonoids content was calculated based on standard curve of rutin $(0.2-1.0 \mathrm{mg} / \mathrm{ml})$ with the linear equation $y=0.0101 x+0.2238$, where $R 2=0.9563$. The results were expressed as $\mu \mathrm{g}$ of rutin equivalent $(\mathrm{RE} / \mu \mathrm{g})$ per gram of the extracts.

\section{Determination of microelements and microelements}

The micro and macronutrients were determined by an atomic absorption spectrophotometric (AAS) method. The samples were digested in nitric acid solution and passed through the AAS system using different lamps. Calibration was done with related minerals in different concentrations for different mineral elements.

\section{Determination of crude protein}

An amount of 0.1 grams of the pulverized mushroom sample was weighed into labelled conical flasks and $5 \mathrm{ml}$ of concentrated $\mathrm{H}_{2} \mathrm{SO}_{4}$ was added and shaken gently. The solution was placed on a preheated sand digester and after heating for a while, drops of $\mathrm{H}_{2} \mathrm{O}_{2}$ was added. The solution was made to cool after which it was topped with distilled water to $100 \mathrm{ml}$ mark of the volumetric flask. An amount of five milliliters of the solution was transferred into a round bottom flask, after which five milliliters of $2 \%$ boric acid solution was added. The solution was distilled in the presence of $5 \mathrm{ml}$ of $40 \% \mathrm{NaOH}$. The distillate was against $0.1 \mathrm{M}$ $\mathrm{HCl}$ until a colour change was observed. The titre value was recorded. The procedure was repeated three times for each sample to minimize error. Percent nitrogen was calculated by using the following formula:

$$
\text { Nitrogen }(\%)=\frac{(\mathrm{a}-\mathrm{b}) \times 0.01 \times 14 \times \mathrm{V} \times 100}{1000 \times \mathrm{W} \times \text { aliquot pipetted }}
$$

Where $a$ represents titre value of sample, $b$, the titre value of the blank, $V$ represents the extraction volume $(100 \mathrm{ml})$ and $W$ represents the weight of the sample $(0.1 \mathrm{~g})$. The crude protein content was estimated by multiplying the percent nitrogen value by the factor 6.25 .

\section{Thin layer chromatography (TLC)}

Methanolic extracts of mushroom samples were separated on silica gel thin layer aluminium plates of $15 \times 5 \mathrm{~cm}$ with $3 \mathrm{~mm}$ thickness. Extracts were spotted manually using capillary tube. Solvent systems used for the separation of the following phytochemical compounds alkaloids, flavonoids, saponins and terpenes were a mixture of chloroform and diethylamine $(9: 1)$, a mixture of chloroform and ethylacetate $(6: 4)$, a mixture of chloroform : methanol : distilled water : toluene $(8: 1: 0.5: 0.5)$ and toluene, respectively. After separation of the phytochemicals compounds, reagents such as iodine and Dragendorff were used to identify the compounds. Colour of the spots was noted and retention factor (Rf) values calculated by using the following formula:

$$
\mathrm{R}_{\mathrm{f}}=\frac{\text { Distance travelled by solute }}{\text { Distance travelled by solvent }} \times 100
$$




\section{RESULTS AND DISCUSSION}

\section{Antioxidant potential}

The extracts of Ganoderma sp showed the strongest activities for DPPH radicals and its $\mathrm{IC}_{50}$ value was $1.56 \times 10^{-4} \mu \mathrm{g} / \mathrm{ml}$ (Table 1 ). The extract for the unknown species gave the lowest activity. Moderate activity was recorded by the extracts of Mycena sp, Marasmus sp, Termitomyces sp and Amauroderma sp.

Radical scavenging activity of mushroom samples studied by Shirmila and Radhamany ${ }^{3}$ was $450 \mu \mathrm{g} / \mathrm{ml}$. The antioxidant potential of the methanolic extracts of the mushroom samples in this study recorded higher values.

\section{Total phenol and flavonoid content}

The highest total phenol content of $17.53 \mathrm{mg}$ gallic acid equivalent $\mathrm{g}$ was recorded for Mycena sp. While the lowest amount was realised from the extract of Amauroderma sp (Table 1). Total phenol content as reported in this work is higher than those reported by Shirmila and Radhamany ${ }^{3}$ who reported a total mean value of $1.901+0.011 \mathrm{mg} \mathrm{GAE} / \mathrm{g}$ of extract.

The highest flavonoid content of $23.75 \mathrm{mg} / \mathrm{g}$ RUE was recorded by Termitomyces sp. whilst Amauroderma sp. gave the lowest amount (Table 1). Total flavonoid content reported in the current study is higher than the value reported by Shirmila and Radhamany ${ }^{3}$. They reported a value of $0.39 \mathrm{mg}$ quercitin equivalent/g of extract. However the values for the current work were lower than those other researchers who reported $248+7.63 \mathrm{mg} / \mathrm{g}$ and $42.063 \mathrm{mg} / \mathrm{g}$ for total phenol and total flavonoid, respectively. ${ }^{19}$

\section{Micronutrient contents of mushrooms}

Amauroderma sp had the lowest content of cadmium $(2.30 \mathrm{mg} / \mathrm{L})$ while the highest content of $8.40 \mathrm{mg} / \mathrm{L}$ was recorded by the unknown sp. (Table 2).
The most abundant micronutrient was found to be iron ranging from $1613.67 \mathrm{mg} / \mathrm{L}$ to $3731.00 \mathrm{mg} / \mathrm{L}$. Iron values in mushroom samples as reported ${ }^{20}$ ranged from $568-3904 \mathrm{lg} / \mathrm{g}$. The iron values of the present study fall within this range.

Lead was highest in extract of Amauroderma sp. while the lowest was recorded for Marasmus sp. Manganese was highest in Marasmus (222.00 $\mathrm{mg} / \mathrm{L})$ and lowest in Ganoderma sp $(26.00 \mathrm{mg} / \mathrm{L})$. Zinc was highest in the unknown sp. (81.90 mg/L) and lowest in Amauroderma sp. (36.97 mg/L). Zinc content of mushroom samples ranged from $33.5-89.5 \mathrm{lg} / \mathrm{g} \cdot{ }^{23}$ Others ${ }^{21,22}$ also reported values that ranged from $29.3-158 \mathrm{lg} / \mathrm{g}$ and $45-188 \mathrm{lg} / \mathrm{g}$, respectively. There were significant differences $(P<0.001)$ among the six different mushroom species with respect to heavy metal content. The manganese content of the mushrooms studied in the present work ranged from $26 \mathrm{mg} / \mathrm{L}$ to $222.00 \mathrm{mg} / \mathrm{L}$. However, others also reported values that ranged from $7.1-91.3 \mathrm{lg} / \mathrm{g},{ }^{22}$ and values that ranged from $21.7-74.3 \mathrm{lg} / \mathrm{g} .{ }^{23}$

\section{Macronutrients and percentage crude protein content of mushrooms}

Marasmus sp. recorded the highest amount of calcium (900.00 mg/L) while Termitomyces sp. scored the lowest $(127.33 \mathrm{mg} / \mathrm{L}$ ) (Table 3), however other researchers recorded lower values of 0.17 to $8.80 \mathrm{mg} / \mathrm{g} \mathrm{dw}{ }^{1}$. Potassium content was highest in the unknown sp. $(5633.33 \mathrm{mg} / \mathrm{L})$ and lowest in Amauroderma sp. (1000.00 mg). These values were higher than those recorded by Huseyin, et al. (2009) which ranged from 12.6-29.1 mg/g $\mathrm{dw}$. The highest amount of magnesium was recorded by the unknown sp. (754.33 mg/L) while the lowest was recorded by Termitomyces sp. (214.67 $\mathrm{mg} / \mathrm{L}$ ). The level of magnesium content reported in this work was higher than those of other researchers who reported values that ranged from $0.90 \mathrm{mg} / \mathrm{g}$ to $4.54 \mathrm{mg} / \mathrm{g} \mathrm{dw}$. Sodium content was highest in the unknown sp. $(9600.00 \mathrm{mg} / \mathrm{L}){ }^{1}$

Table 1: Free radical scavenging activity, total phenolic and total flavonoid mean content of the six mushroom species.

\begin{tabular}{|c|c|c|c|}
\hline Mushroom species & $\begin{array}{l}\text { DPPH scavenging activity } \\
\qquad \mathrm{IC}_{50}(\mu \mathrm{g} / \mathrm{mL}) \\
\left(\times 10^{-4}\right)\end{array}$ & $\begin{array}{c}\text { Total Phenol } \\
\text { (mg/g extract) } \\
\text { in GAE }\end{array}$ & $\begin{array}{l}\text { Total flavonoid } \\
\text { (mg/g extract) } \\
\text { in RUE }\end{array}$ \\
\hline Marasmus & 5.6533 & 9.34100 & 11.23500 \\
\hline Unknown & 21.0667 & 9.05200 & 12.81286 \\
\hline Amauroderma sp. & 7.5200 & 2.54133 & 5.46498 \\
\hline Mycena sp. & 4.6867 & 17.52800 & 9.33410 \\
\hline Termitomyces sp. & 5.6000 & 16.80800 & 23.75048 \\
\hline Ganoderma sp. & 1.5600 & 12.34233 & 17.87333 \\
\hline Mean & 7.68 & 11.26878 & 13.41179 \\
\hline Lsd $_{(0.05)}$ & 1.00 & 0.1959 & 0.0503 \\
\hline
\end{tabular}

Table 2: Mean content of micronutrients in six different mushroom species from the Shai Hills

\begin{tabular}{cccccc}
\hline & Cadmium & Iron & Lead & Manganese & Zinc \\
\hline Marasmus & 2.30 & 3731.00 & 99.00 & 222.00 & 62.30 \\
Unknown & 8.40 & 1816.67 & 155.33 & 61.33 & 81.90 \\
Amauroderma sp. & 8.00 & 3040.00 & 422.33 & 129.00 & 36.97 \\
Mycena sp. & 5.30 & 2207.33 & 120.00 & 70.00 & 70.17 \\
Termitomyces sp. & 7.33 & 1624.67 & 141.67 & 59.00 & 38.87 \\
Ganoderma sp. & 7.73 & 1613.67 & 411.33 & 26.00 & 65.33 \\
Mean & $\mathbf{6 . 5 1}$ & $\mathbf{2 3 3 8 . 8 9}$ & $\mathbf{2 2 4 . 9 4}$ & $\mathbf{9 4 . 5 6}$ & $\mathbf{5 9 . 2 6}$ \\
Lsd $_{(0.05)}$ & $\mathbf{0 . 3 6}$ & $\mathbf{2 1 . 9 3}$ & $\mathbf{3 5 . 6 9}$ & $\mathbf{7 . 2 2}$ & $\mathbf{3 . 4 4}$ \\
\hline
\end{tabular}


Table 3: Mean content of macronutrient and percentage crude protein in six different mushroom species from the Shai Hills

\begin{tabular}{|c|c|c|c|c|c|}
\hline & Calcium & Potassium & Magnesium & Sodium & Protein \\
\hline Unknown & 813.00 & 5633.33 & 754.33 & 9600.00 & 21.24 \\
\hline Amauroderma sp. & 829.67 & 1000.00 & 440.67 & 7433.33 & 11.09 \\
\hline Mycena sp. & 389.67 & 4133.33 & 632.67 & 9333.33 & 28.24 \\
\hline Ganoderma sp. & 134.33 & 3166.67 & 439.00 & 8066.67 & 26.89 \\
\hline Mean & 532.39 & 3550.00 & 515.67 & 8422.22 & 21.64 \\
\hline Lsd $_{(0.05)}$ & 79.44 & 83.86 & 3.458 & 139.07 & 1.01 \\
\hline
\end{tabular}

Table 4: TLC fingerprint for alkaloids in methanolic extracts of six different mushroom species from the Shai Hills

\begin{tabular}{cccccccc}
\hline Fractions & $\mathrm{R}_{\mathrm{f}}$ values & Marasmus & Unknown & Amaurodermasp. & Mycena sp. & $\begin{array}{c}\text { Termitomyces sp. } \\
\text { (nkankuma) }\end{array}$ & Ganoderma sp. \\
\hline 0.49 & - & - & - & + & - & + \\
\hline
\end{tabular}

Table 5: TLC fingerprint for flavonoids in methanolic extracts of six different mushroom species from the Shai Hills

\begin{tabular}{|c|c|c|c|c|c|c|c|}
\hline Fractions & $R_{f}$ values & Marasmus & Unknown & Amauroderma sp. & Mycena sp. & $\begin{array}{l}\text { Termitomyces sp. } \\
\text { (nkankuma) }\end{array}$ & Ganoderma sp. \\
\hline $\mathrm{A}$ & 0.20 & + & - & - & - & - & - \\
\hline B & 0.21 & - & - & - & - & - & + \\
\hline $\mathrm{C}$ & 0.22 & - & + & - & - & - & - \\
\hline $\mathrm{D}$ & 0.23 & - & - & - & + & - & - \\
\hline $\mathrm{EF}$ & 0.25 & - & - & - & - & + & - \\
\hline G & 0.40 & - & - & + & - & - & - \\
\hline $\mathrm{H}$ & 0.43 & - & + & - & - & - & - \\
\hline I & 0.51 & - & - & - & - & + & - \\
\hline $\mathrm{J}$ & 0.63 & - & + & - & - & + & + \\
\hline $\mathrm{K}$ & 0.70 & - & - & - & - & - & + \\
\hline $\mathrm{L}$ & 0.72 & + & - & - & - & - & - \\
\hline M & 0.73 & - & - & - & + & - & - \\
\hline $\mathrm{N}$ & 0.76 & - & - & - & - & - & + \\
\hline $\mathrm{O}$ & 0.87 & - & - & - & - & + & - \\
\hline $\mathrm{P}$ & 0.88 & - & + & - & - & - & - \\
\hline Q & 0.90 & - & - & - & - & - & + \\
\hline $\mathrm{R}$ & 0.96 & - & - & - & - & + & - \\
\hline S & 0.97 & - & + & - & - & - & - \\
\hline \multicolumn{2}{|c|}{ Total number of bands } & 2 & 5 & 1 & 2 & 5 & 5 \\
\hline
\end{tabular}

The highest percentage of crude protein was recorded by Mycena sp. $(28.24 \%)$ and the lowest was recorded by Amauroderma sp. (11.09\%). There were significant differences $(P<0.001)$ among the six mushroom species with reference to the major elements and protein contents (Table 3 ). In a proximate and mineral composition analysis of four edible mushrooms in Nigeria' researchers reported $37 \%$ crude protein in Termitomyces mammiformis. ${ }^{24}$

\section{TLC profile for alkaloid}

Alkaloid was present in only Mycena sp and Ganoderma sp with a band each of $R_{f}$ value of 0.49 (Table 4 ).

\section{TLC profile for flavonoid}

A total of 18 different bands were recorded with $\mathrm{R}_{\mathrm{f}}$ values that ranged between 0.20 and 0.97 (Table 5). Two different bands were recorded by the Marasmus sp. with $\mathrm{R}_{\mathrm{f}}$ values of 0.2 and 0.72 , respectively. Five different bands were recorded by the unknown sp. with $\mathrm{R}_{\mathrm{f}}$ values of $0.22,0.43$, 0.63 and 0.88 , respectively. Amauroderma sp. recorded only one band with $\mathrm{R}_{\mathrm{f}}$ value of 0.40 . Mycena sp. recorded a total of two different bands of $R_{f}$ values of 0.23 and 0.73 , respectively. A total of five different bands were recorded by Termitomyces sp. with $\mathrm{R}_{\mathrm{f}}$ values of $0.25,0.51,0.63,0.97$ and 0.97 , respectively. The Ganoderma sp. also recorded a total of five 
Table 6: TLC fingerprint for saponins in methanolic extracts of six different mushroom species from the Shai Hills

\begin{tabular}{|c|c|c|c|c|c|c|c|}
\hline Fractions & $R_{f}$ values & Marasmus & Unknown & Amauroderma sp. & Mycena sp. & $\begin{array}{l}\text { Termitomyces sp. } \\
\text { (nkankuma) }\end{array}$ & Ganoderma sp. \\
\hline A & 0.16 & - & + & - & - & - & - \\
\hline B & 0.41 & - & + & - & - & - & - \\
\hline $\mathrm{C}$ & 0.44 & - & - & - & - & + & - \\
\hline $\mathrm{D}$ & 0.59 & + & - & - & - & - & - \\
\hline $\mathrm{E}$ & 0.62 & - & - & - & - & - & + \\
\hline $\mathrm{F}$ & 0.66 & + & - & - & - & - & - \\
\hline G & 0.68 & - & - & - & + & - & + \\
\hline $\mathrm{H}$ & 0.69 & - & - & - & + & - & - \\
\hline I & 0.71 & - & - & + & - & - & - \\
\hline $\mathrm{J}$ & 0.73 & - & + & - & - & - & - \\
\hline $\mathrm{K}$ & 0.78 & - & - & + & - & - & - \\
\hline $\mathrm{L}$ & 0.79 & - & + & - & - & - & - \\
\hline M & 0.88 & - & - & - & - & + & - \\
\hline $\mathrm{N}$ & 0.94 & + & - & - & + & - & + \\
\hline $\mathrm{O}$ & 0.99 & + & - & - & - & - & + \\
\hline \multicolumn{2}{|c|}{ Total number of bands } & 4 & 4 & 2 & 3 & 2 & 4 \\
\hline
\end{tabular}

Table 7: TLC fingerprint for terpenes in methanolic extracts of six different mushroom species from the Shai Hills

\begin{tabular}{|c|c|c|c|c|c|c|c|}
\hline Fractions & $R_{f}$ values & Marasmus & Unknown & Amauroderma sp. & Mycena sp. & Termitomyces sp. & Ganoderma sp. \\
\hline A & 0.07 & - & + & + & - & - & - \\
\hline B & 0.10 & + & - & - & - & - & - \\
\hline $\mathrm{C}$ & 0.11 & - & - & - & + & - & - \\
\hline $\mathrm{D}$ & 0.13 & - & - & - & - & - & + \\
\hline $\mathrm{E}$ & 0.16 & - & - & - & - & + & - \\
\hline $\mathrm{F}$ & 0.27 & - & + & - & - & - & - \\
\hline G & 0.28 & - & - & - & - & + & - \\
\hline $\mathrm{H}$ & 0.31 & - & - & - & - & - & + \\
\hline I & 0.37 & - & - & + & - & - & - \\
\hline $\mathrm{J}$ & 0.43 & - & - & - & - & - & + \\
\hline K & 0.55 & - & - & - & - & + & - \\
\hline $\mathrm{L}$ & 0.56 & - & + & + & - & - & - \\
\hline $\mathrm{M}$ & 0.61 & + & - & - & + & - & + \\
\hline \multicolumn{2}{|c|}{ Total number of bands } & 2 & 3 & 3 & 2 & 3 & 4 \\
\hline
\end{tabular}

different bands of $\mathrm{R}_{\mathrm{f}}$ values of $0.21,0.63,0.70,0.76$ and 0.90 , respectively. The band with $\mathrm{R}_{\mathrm{f}}$ value of 0.63 was common to the unknown species, Termitomyces sp. and the Ganoderma sp.

\section{TLC profile for saponin}

A total of 15 different bands were recorded with $\mathrm{R}_{\mathrm{f}}$ values ranging from 0.16 to 0.99 (Table 6). Extracts of Marasmus sp. recorded a total of four different bands with $\mathrm{R}_{\mathrm{f}}$ values of $0.59,0.66,0.94$ and 0.99 , respectively. A total of four different bands were recorded by extracts from the unknown sp. at $\mathrm{R}_{\mathrm{f}}$ values of $0.16,0.41,0.73$ and 0.79 , respectively. Extracts of the Amauroderma sp. gave two bands with $\mathrm{R}_{\mathrm{f}}$ values of 0.71 and 0.78 , respectively. A total of three different bands were recorded by extracts from the Mycena sp. with $\mathrm{R}_{\mathrm{f}}$ values of $0.68,0.69$ and 0.94 , respectively.
Extracts of the Termitomyces sp. gave a total of two different bands with $\mathrm{R}_{\mathrm{f}}$ values of 0.44 and 0.88 , respectively. The Ganoderma sp. extracts gave a total of four different bands with $\mathrm{R}_{\mathrm{f}}$ values of $0.62,0.68,0.94$ and 0.99 , respectively. The band with $\mathrm{R}_{\mathrm{f}}$ value of 0.68 was common to the Mycena and Ganoderma spp. The band with the $\mathrm{R}_{\mathrm{f}}$ value of 0.84 was common to the Marasmus, Mycena and Ganoderma spp. Similarly the band with the $\mathrm{R}_{\mathrm{f}}$ value of 0.99 was common to the Marasmus and Ganoderma spp.

\section{TLC profile for terpene}

A total of 13 different bands were scored with $R_{f}$ values ranging between 0.07 and 0.61 (Table 7). Extracts from the Marasmus sp. recorded a total of 2 different bands with $\mathrm{R}_{\mathrm{f}}$ values of 0.10 and 0.61 , respectively. Extracts from the unknown sp. recorded a total of three different bands of $R_{f}$ values 
of $0.07,0.27$ and 0.56 , respectively. The Amauroderma sp. extracts gave a total of three different bands with $\mathrm{R}_{\mathrm{f}}$ values of $0.07,0.37$ and 0.56 , respectively. Extracts from the Mycena sp. gave a total of 2 bands with $\mathrm{R}_{\mathrm{f}}$ values of 0.11 and 0.61 , respectively. The extracts from Termitomyces $\mathrm{sp}$ recorded a total of three different bands with $R_{f}$ values of $0.16,0.28$ and 0.55 , respectively. The Ganoderma sp. extracts gave a total of four different bands with $\mathrm{R}_{\mathrm{f}}$ values of $0.13,0.31,0.43$ and 0.61 , respectively. The bands with $\mathrm{R}_{\mathrm{f}}$ value of 0.07 and 0.56 was common to the unknown and Amauroderma spp. Similarly, the band with $\mathrm{R}_{\mathrm{f}}$ value 0.61 was common to the Mycena and Ganoderma sp.

TLC profiles of mushrooms is a new area of research in Ghana. The TLC revealed the presence of single alkaloid compound which was present in only Mycena. The highest number of flavonoid compounds was detected in extracts of Ganoderma sp, Termitomyces and the unknown sp. concerning saponin profile the highest number of compounds were present in extracts of Marasmus sp. Ganoderma and the unknown sp. The highest number of terpene compounds was detected in extracts of Ganoderma sp.

\section{CONCLUSION}

The antioxidant potential of the methanolic extracts of the mushroom samples in this study recorded higher values. This indicates that mushrooms have high antioxidant properties and rationalizes further investigation in the potential discovery of new natural bioactive principles from these mushrooms.

\section{ACKNOWLEDGEMENT}

The authors are grateful to the office of research and innovative division of the University of Ghana for providing funds for the research.

\section{CONFLICT OF INTEREST}

None

\section{ABBREVIATIONS USED}

AAS: Atomic absorption spectrophotometric; DPPH: 1, 1-diphenyl2-picrylhydrazyl; IC $_{50}$ : half maximal inhibitory concentration; GAE: Gallic acid equivalent; $\mathbf{R}_{\mathrm{f}}$ : Representative Fraction; RUE: Rutin equivalent; TLC: Thin layer chromatography.

\section{REFERENCES}

1. Huseyin G, Yusuf U, Yusuf T, Kenan D. Determination of mineral contents of wild-grown edible mushrooms. Food Chemistry. 2009; 113(4):1033-6

2. Racz, L, Papp L, Prokai B, Kovacz Z. Trace element determination in cultivated mushrooms: an investigation of manganese, nickel, and cadmium intake in cultivated mushrooms using ICP atomic emission. Microchemical Journal, 1996;54(4):444-51
3. Shirmila Jose G Radhamany PM. Identification and determination of antioxidant constituents of bioluminescent mushroom. Asian Pacific Journal of Tropical Biomedicine 2012;386-S391

4. Terpinc, P, Abramovic H. A kinetic approach for evaluation of the antioxidant activity of selected phenolic acids. Food Chemistry. 2010;121(2):366-71.

5. Orhan I, Üstün O. Determination of total phenol content, antioxidant activity and acetylcholinesterase inhibition in selected mushrooms from Turkey. Journal of Food Composition and Analysis. 2011;24(3):386-90.

6. Vaz JA, Barros L, Martins, A, Santos-Buelga C, Vasconcelos, Ferreira, ICFR. Chemical composition of wild edible mushrooms and antioxidant properties of their water soluble polysaccharidic and ethanolic fractions. Food Chem, $2011 ; 126(2): 610-6$.

7. García-Lafuente A, Moro C, Villares A, Guillamón, E, Rostagno MA, D’Arrigo M. Martínez JA. Mushrooms as a source of anti-inflammatory agents. American Journal of Community Psychology 2011;48(2):125-41.

8. Nikolova M,Valyovska-Popova N, Dimitrova M, Peev .D. High-mountain Bulgarian plants - free radical scavenging activity and flavonoid composition Nikolova et al. J. BioSci. Biotech. 2014;SE/ONLINE:29-33

9. Mohammad A, Bhawani SA, Sharma S. Analysis of herbal products by thin-layer chromatography: a review. Int. J. Pharma Bio Sci. 2010;1(2):1-50.

10. Braz R, Wolf LG, Lopes GC, deMello JCP. Quality control and TLC profile data on selected plant species commonly found in the Brazilian market. Rev. Bras. Farmacogn, 2012;22(5):1111-8.

11. Helftmann F. Chromatography:- Fundamental and applications of chromatographic and Electrophoretic Techniques, 5th edition, Elsevier, Amsterdam, 1992;520-2

12. Hahn-Deinstrop, E. Applied thin layer chromatography best practice and avoidance of mistakes. Wilkey.VCH, Weinheim, Germany; 2000.

13. Wagner H, Bladt S, Zgainski EM. Plant drug analysis. Athin layer chromatography altlas. Springer-Verlag. Berlin Heidelberg New York Tokyo. 1984.1:309.

14. Roger P. Mushrooms and other Fungi of Great Britain and Europe. Irish Book Center; 1st Ed. edition 1989. ISBN-10: 0330264419

15. Pegler D, Spooner B. The Mushroom Identifier. 1992. Published by The Apple Press. ISBN 1-85075-361-5

16. Tsai SY, Huang SJ, Lo, SH, Wu TP, Lian, PY, Mau, JL. Flavour components and antioxidant properties of several cultivated mushrooms. Food Chemistry. 2009; 13:(2)578-84.

17. Harborne JB. General procedures and measurement of total phenolics. Methods in plant biochemistry. 1989;1:1-28.

18. Barros L, Ferreira, MJ, Queiros B, Ferreira I, Baptista P. Total phenols, ascorbic acid, betacarotene and lycopene in Portuguese wild edible mushrooms and their antioxidant activities. Food Chemistry. 2007;103(2):413-9

19. Hamzah RU, Jigam AA, Makun HM, Egwim EC. Phytochemical screening and antioxidant activity of methanolic extract of selected wild edible Nigerian mushrooms. Asian Pac J Trop Dis 2014;4:153-7

20. Turkekul I, Elmastas M, Tuzen M. Determination of iron, copper, manganese zinc, lead, and cadmium in mushroom samples from Tokat, Turkey. Food Chemistry. 2004;84(3):389-92.

21. Isılog lu M, Yilmaz F, Merdivan M. Concentrations of trace elements in wild edible mushrooms. Food Chemistry. 2001;73(2):163-75

22. Tuzen, M. Determination of heavy metals in soil, mushroom and plant samples by atomic absorption spectrometry. Micro chemical Journal. 2000;74(3):289-97.

23. Soylak, M, Saracoglu, S, Tuzen, M, Mendil, D. Determination of trace metals in mushroom samples from Kayseri, Turkey. Food Chemistry. 2005;92(4):649-52

24. Adejumo, TO. Awosanya, OB. Proximate and mineral composition of four edible mushroom species from South Western Nigeria African. Journal of Biotechnology. 2005;10(10):1084-8

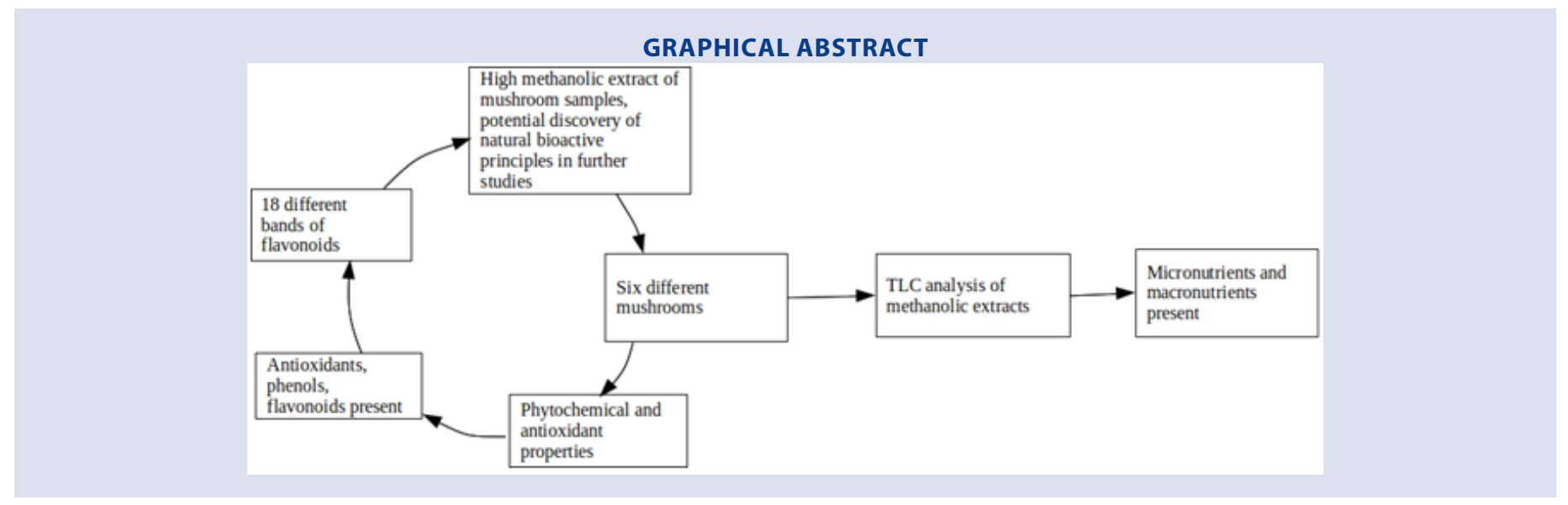




\section{SUMMARY}

- Phytochemical analyses of the methanolic extract of the mushrooms revealed the presence of antioxidants, phenols and flavonoids.

- The highest number of flavonoid compounds was detected in extracts of Ganoderma sp, Termitomyces and the unknown sp.

- There is the need for further investigation with the view of discovering new natural bioactive principles from these mushrooms.

- TLC profiles of mushrooms is a new area of research in Ghana.

\section{ABOUT AUTHORS}

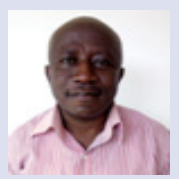

Dr. Ebenezer Owusu is a Senior Lecturer at the Department of Plant and Environmental Biology at the University of Ghana. He is a member of many scientific associations and has publications in many peer-reviewed journals.

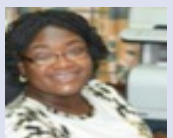

Mrs. Gladys Schwinger was an Assistant Lecturer at the Department of Plant and Environmental Biology at the University of Ghana. She is currently pursuing a PhD degree at the Institute for Environmental and Sanitation Studies (IESS), University of Ghana.

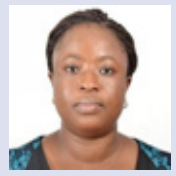

Matilda Dzomeku is a Research Scientist and the head of the mushroom laboratory of CSIR-Food Research Institute.

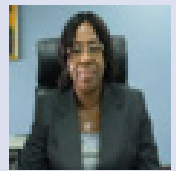

Professor Mary Obodai is a Principal Research Scientist and the Director of CSIR-Food Research Institute. She is an Associate Professor at the CSIR college of Science and Technology.

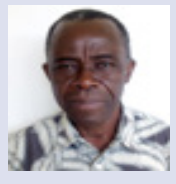

Professor I. K. Asante is professor and Head of the Department of Plant and Environmental Biology at the University of Ghana. He has published extensively in many peer-reviewed journals.

Cite this article: Owusu E, Schwinger G, Dzomeku M, Obodai M and Asante I. Phytochemical, Free Radical Scavenging Activity and Thin Layer Chromatography Analysis of Methanolic Extracts of Six Wild Mushroom Species Collected From the Shai Hills Reserve of Ghana. Pharmacog J. 2017;9(6)suppl:s16-s22. 